\title{
Preliminary assessment of the impact of long-term fire treatments on in situ soil hydrology in the Kruger National Park
}

\begin{abstract}
Authors:
Edward S. Riddell

Ahmed Khan ${ }^{1}$

Benjamin Mauck ${ }^{1}$

Simphiwe Ngcobo $^{1}$

Jonathan Pasi ${ }^{1}$

Andrew Pickles ${ }^{1}$

Jennifer Pickles ${ }^{1}$

Zinhle Sithole ${ }^{1}$

Simon A. Lorent $z^{1}$

Navashni Govender ${ }^{2}$

Affiliations:

${ }^{1}$ School of Agriculture, Earth and Environmental Science, University of KwaZulu-Natal, Pietermaritzburg campus,

South Africa

${ }^{2}$ Scientific Services, South African National Parks, Kruger National Park, South Africa

Correspondence to:

Edward Riddell

Email:

riddelle@ukzn.ac.za

Postal address:

Private Bag X01, Scottsville

3209, South Africa

Dates:

Received: 23 Dec. 2011

Accepted: 08 May 2012

Published: 27 July 2012

How to cite this article: Riddell, E.S., Khan, A.,

Mauck, B., Ngcobo, S., Pasi, J., Pickles, A. et al., 2012,

'Preliminary assessment of the impact of long-term fire treatments on in situ soil hydrology in the Kruger National Park', Koedoe 54(1), Art. \#1070, 7 pages. http:// dx.doi.org/10.4102/koedoe. v54i1.1070
\end{abstract}

(C) 2012. The Authors. Licensee: AOSIS OpenJournals. This work is licensed under the Creative Commons Attribution License.
There has been significant attention focused on the impacts of fire frequency and season of burn on ecological processes in the Kruger National Park (KNP). Whilst there has been some examination of these fire effects on soil properties, the explicit linkages of these effects to the hydrology of soils in burnt areas has remained a gap in our understanding. During August 2010, a field scoping campaign was undertaken to assess the impacts, if any, of long-term fire treatments on the hydrology of soils on the experimental burn plots (EBPs) in the KNP. Using various hydrometric and soil physical characterisation instruments soil, hydraulic conductivity and soil strength variations were determined across the extreme fire treatment on the EBPs, the annual August (high fire frequency) plots and the control (no burn) plots, on both the granite and basalt geologies of Pretoriuskop and Satara, respectively. It was found that there were soil hydrological and structural differences to fire treatments on the basalt burn plots, but that these were not as clear on the granite burn plots. In particular, hot, frequent fires appeared to reduce the variation in soil hydraulic conductivity on the annual burn plots on the basalts and led to reduced cohesive soil strength at the surface.

Conservation implications: The KNP burn plots are one of the longest running and well studied fire experiments on African savannahs. However, the impacts of fire management on hydrological processes in these water-limited ecosystems remains a gap in our understanding and needs to be considered within the context of climate and land-use changes in the savannah biome.

\section{Introduction}

Savannahs are tropical grasslands with scattered trees; they occupy about $20 \%$ of the land surface of the Earth and $40 \%$ of Africa (Scholes \& Hall 1996). These ecosystems are dynamic in their structure, composition and function. Fire is an important driver in savannah ecosystems, where it acts as both a generalist herbivore (Bond \& Keeley 2005) and as a facilitator of the coexistence of trees and grasses (Higgins, Bond \& Trollope 2000). The spatio-temporal availability of water is also considered a key driver of savannah heterogeneity (Walter 1971). Studies of catchment hydrological processes response to natural and induced fires have received the greatest attention in various land-systems within Australia (e.g. Brown 1972; Townsend \& Douglas 2000). Studies elsewhere include mountain catchments under exotic forestry (Scott 1997) and fynbos (Lindley, Bosch \& Van Wyk 1988) in South Africa; however, few studies have examined explicitly pyrohydrological interactions and the role of various burning regimes within African savannahs (Scholes \& Walker 1993).

Fire has long been used in the management of savannahs and this management has been informed and adapted by the findings of ongoing research on experimental sites of selected fire regimes on fixed areas (Andersen, Cook \& Williams 2003; Knapp et al. 1998). The long-term fire experiment in the Kruger National Park (KNP) was established in 1954, with the initial objectives being to study the effects of fire frequency and season on the vegetation of the KNP under indigenous grazing pressure (Van der Schijff 1958). The experimental burn plots (EBPs) were laid out in four of the 37 main vegetation landscapes of the KNP described by Gertenbach (1983): the Pretoriuskop sourveld vegetation, Skukuza Combretrum vegetation, Satara Knobthorn and Marula vegetation and Mopani Mopane vegetation.

Whilst there has been some examination of fire effects on in situ soil properties, the explicit linkages of these to the hydrological parameters of soils in burnt areas has remained a knowledge gap (Pierson et al. 2011). To date, a variety of soil hydrological responses have been described; for instance, frequent burning reduced the rate of infiltration of rainwater into soil as noted in the Drakensberg (Bijker et al. 2001). This is caused by crusting of the soil, thereby yielding lower 
electrical conductivity as a result of the removal of ash via increased surface water runoff and increasing soil erosion and as shown particularly for the granite EBPs in the KNP (Mills \& Fey 2004). Webber (1979) showed that the unburnt control EBPs near Skukuza retained greater moisture levels well into the dry season and, where burning occurred on duplex soils, this made them susceptible to erosion.

In light of these previous findings, the objectives of this study therefore were to determine the impacts, if any, of long-term high fire frequency and intensity treatments versus fire exclusion on in situ soil hydrological characteristics in the KNP. Moreover, this included an assessment of the effects of potential fire impacts on soil hydrology in the two distinct geologies of the KNP: the granites and basalts.

\section{Research method and design}

The August 2010 field campaign focused on describing various in situ soil hydraulic and strength characteristics on these plots on the two extreme fire treatments, within an EBP string, on the two dominant geologies in the KNP, namely the granites at Pretoriuskop (Lowveld Sour Bushveld, sandy soils with mean annual precipitation [MAP] of $737 \mathrm{~mm}$ ) and basalts at Satara (Acacia nigrescens savannah, clay soils with MAP of $537 \mathrm{~mm}$ ) (Biggs et al. 2003). An EBP string is located generally along the crests of the hillslope and consists of twelve to fourteen 7 ha plots bounded by fire breaks to prevent natural and accidental fires from entering them. The fire treatments include winter August (dry season, hot), October (first spring rains), December (early summer wet season), February (late summer) and April (autumn) with annual, biennial and triennial treatments.

Because one string at both sites was deemed unrepresentative of the broader landscapes (Venter \& Govender 2012), only three of the four strings at these sites were assessed, as shown in Figure 1.

A semi-systematic approach was taken in order to dismiss the inherent variability associated with the different soil morphologies linked to subtle changes in topography. Predetermined areas were selected according to diagnostic soil form characteristics, identified by a soil scientist (Le Roux pers. comm., 06 March 2010), which resulted in attention to sites characteristic of the Shortlands and Huttons soil forms (Soil Classification Working Group 1991) which were identified as being dominant on the basalt and granite plots, respectively. The reader is referred to Venter and Govender (2012) for detailed descriptions of the soil morphologies on the EBPs. Hydrological measurements and soil characterisations were then taken randomly within these areas.

A variety of techniques were used to determine the soils' hydraulic conductivity within $30 \mathrm{~cm}$ of the soil surface. These included:

- Double-ring infiltrometers, to determine saturated soil conductivities $\left(K_{\text {sat }}\right)$ at the soil surface, according to the method of Lorentz et al. (2003).

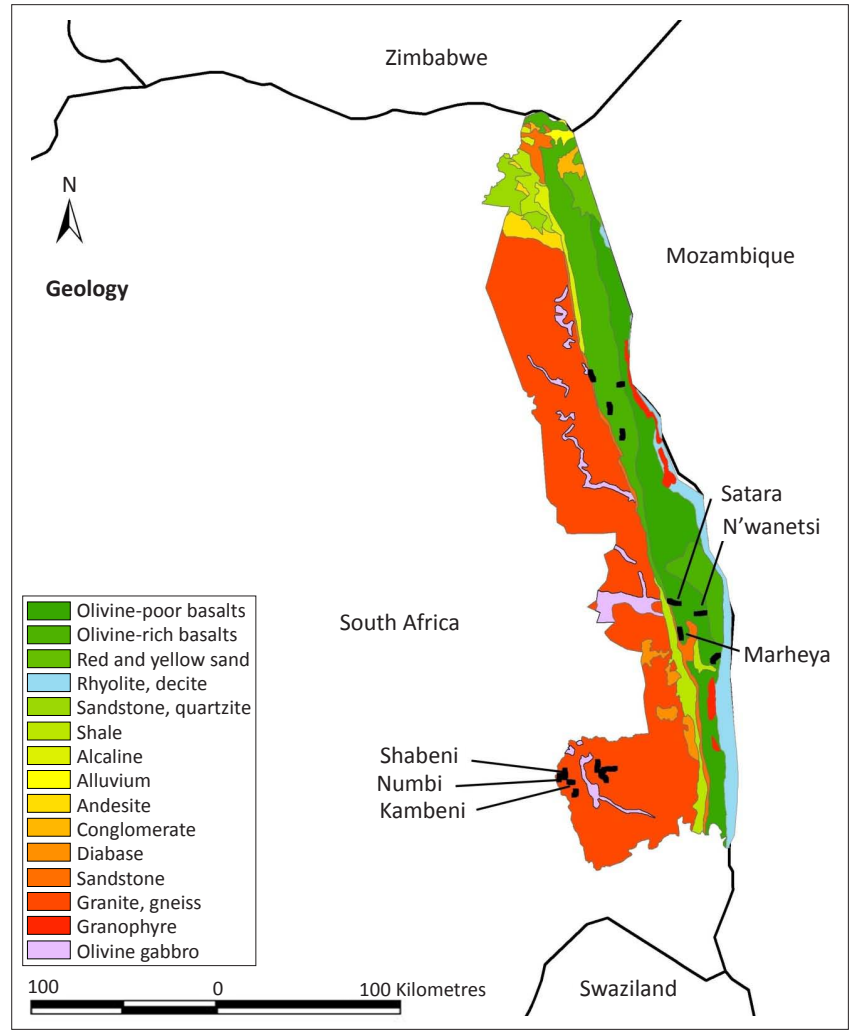

FIGURE 1: The Kruger National Park experimental burn plot strings assessed in this study.

- Guelph permeameters, to determine $K_{\text {sat }}$ within the subsurface at $5 \mathrm{~cm}, 15 \mathrm{~cm}$ and $30 \mathrm{~cm}$ depths (Eijkelkamp Agrisearch Equipment 2008).

- Tension disc infiltrometers, to determine unsaturated soil conductivities $\left(K_{\text {unsat }}\right)$ at the soil surface, according to the method of Lorentz et al. (2003).

Two replicates of each of the above techniques were made at each EBP treatment per landscape and results are discussed simply based on visual interrogation of the data. Sampling sites were selected in a semi-random manner by first identifying areas a minimum of $10 \mathrm{~m}$ from large trees and $15 \mathrm{~m}$ from the fire breaks and then randomly placing instruments on bare ground. The unconfined cohesive soil strength on the EBPs was assessed using the following equipment:

- a dynamic cone penetrometer (Herrick \& Jones 2002), consisting of a $1 \mathrm{~cm}$ diameter rod, conical extremity of $90^{\circ}$ and a $2 \mathrm{~kg}$ weight dropped from a height of $100 \mathrm{~cm}$

- a pocket penetrometer (Eijkelkamp Agrisearch Equipment 2009)

- a pocket vane tester (Eijkelkamp Agrisearch Equipment 2011).

These assessments were performed within a $5 \mathrm{~m}$ radius of the hydrology measurements and typically 10 readings were taken at each of the EBPs randomly within the immediate vicinity of the soil hydrology measurements. The resulting data was then subject to non-parametric statistical analysis using the Mann-Whitney $U$-test for unmatched samples using the STATEXT v. 1.4 software (2011). 


\section{Results}

The $K_{\text {sat }}$ values determined at the soil surface of the granite EBPs clearly illustrate higher variation across all the plots and between fire treatments (Figure 2). Unfortunately, no measurements were taken on the Numbi control plot; however, it was noted that, for both replicates, the Shabeni control plots had significantly greater $K_{\text {sat }}$ values than the annual burn plots. At Kambeni, the annual and control plots had similar $K_{\text {sat }}$ values, although in both replicates the values were slightly lower for the control. The $K_{\text {sat }}$ values for the basalt EBPs had generally lower variation than the granite EBPs (Figure 3). With the exception of Marheya Replicate 1 $\left(0.015 \mathrm{~cm} / \mathrm{s}^{-1}\right.$ beyond the axis range), there appeared to be no distinct difference in the $K_{\text {sat }}$ between annual or control treatments on the basalt EBPs.

The results of $K_{\text {sat }}$ tests at depths between $5 \mathrm{~cm}$ and $30 \mathrm{~cm}$ (as depicted in Figure 2 and Figure 3) revealed that soils on the granite EBPs have, on average, a greater hydraulic conductivity on the annual frequent burn plots than the control plots; this was most noticeable at Kambeni and Shabeni. There was also a switch in the trend of $K_{\text {sat }}$ where annual burn plots had lower $K_{\text {sat }}$ at the soil surface than the control plots, a trend which reversed at depth. Interestingly, it appeared that there was less variation in $K_{\text {sat }}$ at $5 \mathrm{~cm}$ within the control treatments on the granite EBPs. The $K_{\text {sat }}$ distribution of the basalt EBPs, meanwhile, was an order of magnitude lower than the granite EBPs; however, there was no distinct difference in $K_{\text {sat }}$ between annual and control treatments in the soil sub-surface.

Figure 4 shows the $K_{\text {unsat }}$ values of the granite EBPs soil surface, where, on average, the annual burn plots tended to have greater $K_{\text {unsat }}$ than the controls. Also, there was a distinctly greater $K_{\text {unsat }}$ on the annual burn plots at the lowest soil moisture tensions close to saturation $(0.5 \mathrm{~cm})$. The opposite trend of the annual EBPs having a lower $K_{\text {unsat }}$ on average than the controls was demonstrated on the basalt EBPs (Figure 5). The outliers to the above trend on the basalt EBPs were the Marheya string and, with the exception of the Satara annual plot replicate, the controls had greater variation in $K_{\text {unsat }}$ than the annual burn plots.

Drop cone penetrometer tests for granite EBPs revealed that the first approximate $150 \mathrm{~J}$ was the threshold for maximum depth penetration across annual and control plots; thereafter, there was a steady increase in depth at each energy increment (Figure 6). The greatest variations in soil strength properties were noted for control plots compared to annual burn plots on the soil of the granite EBPs. Whilst with the basalt EBPs (Figure 7), it was the annual plots which again had distinctly less variation in soil strength compared to the control plots. An interesting aspect depicted in Figure 7 was the slightly lower threshold in energy over depth, which was reached at about $130 \mathrm{~J}$ before further energy resulted in less depth penetration.

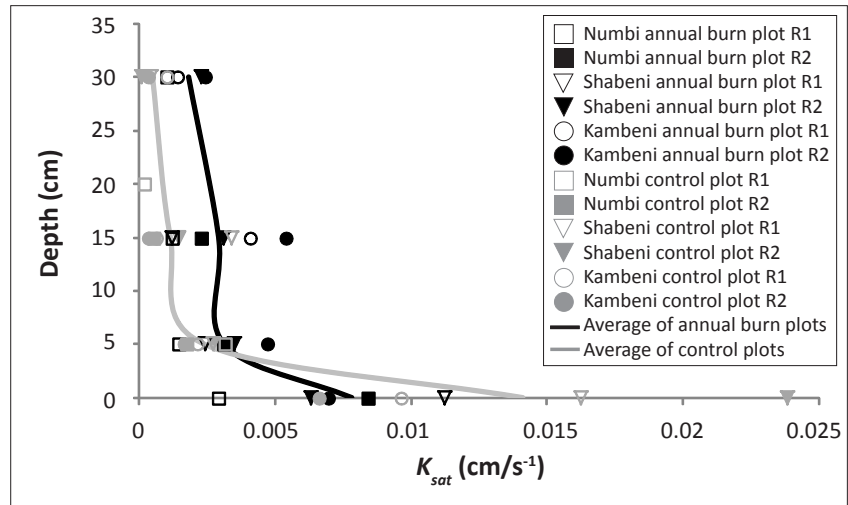

$K_{\text {sat }}$, saturated soil conductivities; R1, Replicate 1; R2, Replicate 2 .

FIGURE 2: Field saturated hydraulic conductivity versus depth on the granite experimental burn plots in the Kruger National Park.

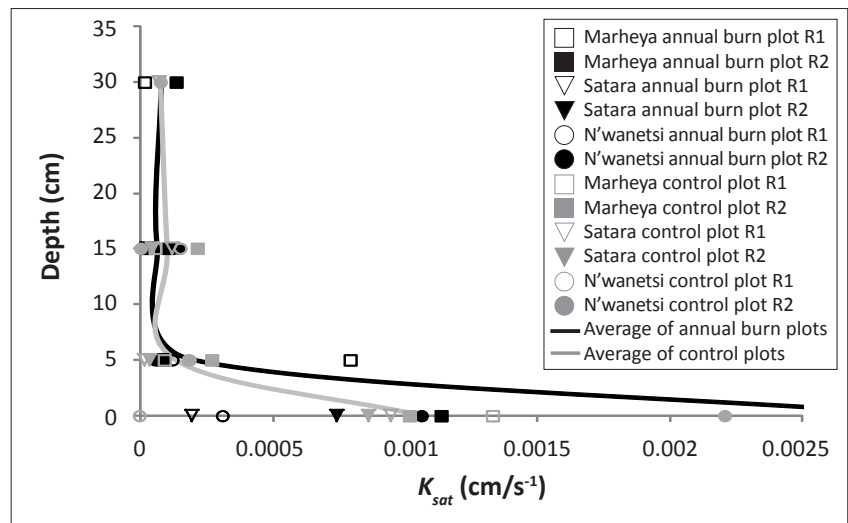

$K_{\text {sar }}$ saturated soil conductivities; R1, Replicate 1; R2, Replicate 2.

FIGURE 3: Field saturated hydraulic conductivity versus depth on the basalt experimental burn plots in the Kruger National Park.

Table 1 presents the statistical results of the raw drop cone penetrometer data at two energy levels $(2 \mathrm{~kg} \times 2 \mathrm{~kg}$ weight drops, or $34 \mathrm{~J} / \mathrm{cm}^{-2}$ and $10 \mathrm{~kg} \times 2 \mathrm{~kg}$ weight drops, or $307 \mathrm{~J} / \mathrm{cm}^{-2}$ ). There was no significant difference in the cohesive soil strength between control and annual burn plots on the granite EBPs; however, the basalt EBPs showed a significantly greater mean depth of penetration at both energy levels on the annual burn plots. The pocket penetrometer data supported this with no significant difference on the granite EBPs, but there was a statistical difference on the basalt EBPs. No significant difference was observed within the soil shear strength between annual and control treatments on both geological settings.

\section{Trustworthiness}

The data presented in these results are based on human measurements and thus aspects pertaining to the trustworthiness of the collected data need to be considered in the following contexts.

\section{Reliability}

Repeatability of acquiring the same results of both the $K_{\text {unsat }}$ and $K_{\text {sat }}$ measurements is achieved from standard in situ hydrological measurements. However, replication of 
TABLE 1: Mann-Whitney $U$-test results for unconfined cohesive soil strength parameters in the Kruger National Park.

\begin{tabular}{|c|c|c|c|c|c|c|c|c|c|}
\hline \multirow[t]{2}{*}{ Instrument } & \multirow[t]{2}{*}{ Fire treatment } & \multicolumn{4}{|c|}{ Basalt } & \multicolumn{4}{|c|}{ Granite } \\
\hline & & $N$ & Mean & $U$ & $p$ & $N$ & Mean & $U$ & $p$ \\
\hline \multirow[t]{2}{*}{ Pocket penetrometer $\left(\mathrm{Kg} / \mathrm{cm}^{-2}\right)$} & Annual & 62 & 2.51 & 1295.0 & 0.000 & 22 & 2.05 & 233.5 & 0.100 \\
\hline & Control & 69 & 1.82 & & & 27 & 1.62 & & \\
\hline \multirow[t]{2}{*}{ Pocket vane tester $\left(\mathrm{Kg} / \mathrm{cm}^{-2}\right)$} & Annual & 46 & 2.63 & 814.0 & 0.295 & 22 & 2.27 & 262.0 & 0.483 \\
\hline & Control & 38 & 2.74 & & & 24 & 1.94 & & \\
\hline Drop cone penetrometer $\left(34 \mathrm{~J} / \mathrm{cm}^{-2}\right)$ & Annual & 30 & 2.18 & 283.5 & 0.006 & 30 & 1.76 & 327.5 & 0.107 \\
\hline \multirow[t]{2}{*}{ Drop cone penetrometer $\left(307 \mathrm{~J} / \mathrm{cm}^{-2}\right)$} & Annual & 30 & 4.67 & 332.5 & 0.041 & 30 & 4.80 & 385.0 & 0.458 \\
\hline & Control & 30 & 4.04 & & & 27 & 4.77 & & \\
\hline
\end{tabular}

No differentiation of the experimental burn plots string within the analysis.

$N$, number of observations; $U$, Mann-Whitney $U$ statistic; $p$, probability of significance.

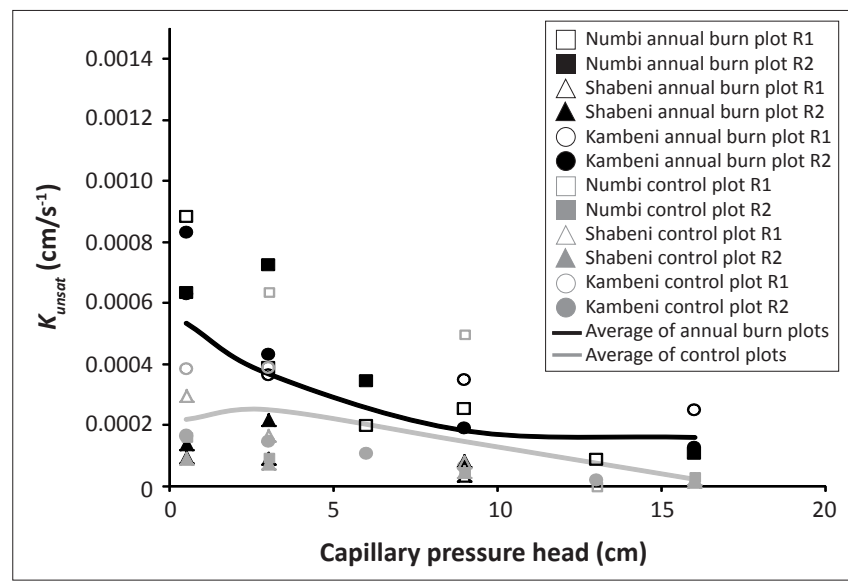

$K_{\text {unsar }}$ unsaturated soil conductivities; R1, Replicate 1; R2, Replicate 2.

FIGURE 4: Unsaturated hydraulic conductivity at the surface of the granite experimental burn plots in the Kruger National Park.

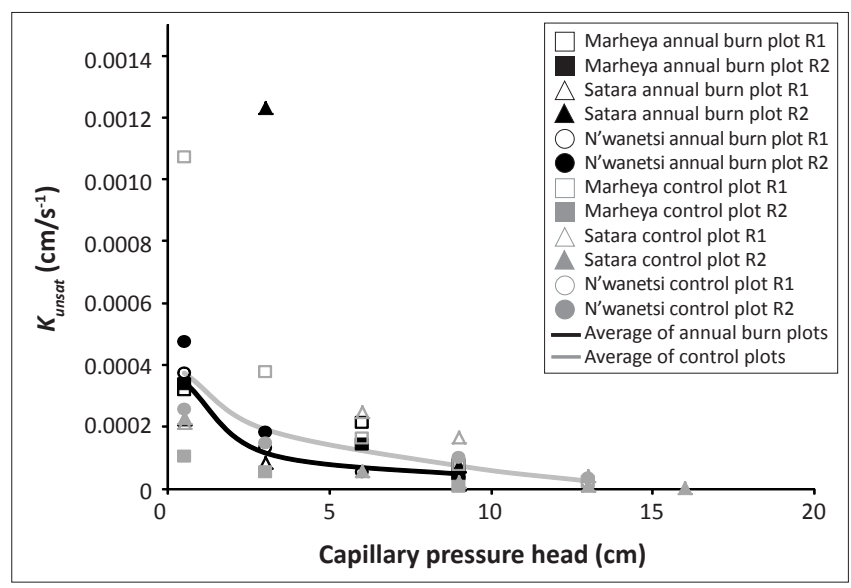

$K_{\text {unsar }}$ unsaturated soil conductivities; R1, Replicate 1; R2, Replicate.

FIGURE 5: Unsaturated hydraulic conductivity at the surface of the basalt experimental burn plots in the Kruger National Park.

the results would require the placing of the instruments at precisely the same locations, otherwise inherent heterogeneities in the soil matrix would yield different results. A potential observer bias arises when determining whether $K_{\text {unsat }}$ and $K_{\text {sat }}$ is reached at a steady-state infiltration rate. To ensure that this bias inherently did not affect the collected data, we followed the convention of 10 equal time intervals per volume of water infiltrated interval (for further details consult Lorentz et al. 2003).
The same principle applies for soil strength characteristics determined via the drop cone penetrometer method, where consistency of measurements is achieved by the dropping of a known weight from a standard height on the penetrometer device. However, reliability of the data may be questioned should the penetrometer not be held vertically above the soil. Care was taken during this study to ensure that each measurement was taken with a vertical deployment of the penetrometer device. Similarly, this principle also applies to the pocket penetrometer and pocket vane tester. However, we did observe a potential effect of pressure applied to the soil surface and angle of contact by these devices, meaning that each operator has the potential to influence the outcome of the measurement. To minimise this risk, the same operator conducted these measurements during this study.

\section{Validity}

The validity of the reported measurements was believed by the authors to be appropriate to achieving the objectives of this scoping exercise within these specific study areas. Nevertheless, significantly greater replication of these measurements should be performed in future to quantify the variability of results from significant soil surface spatial heterogeneities on the EBPs and to answer comprehensively those causal mechanisms postulated in the following discussion.

\section{Discussion}

These measurements reveal interesting differences across the soils associated with the two geologies of granite and basalt in relation to long-term fire and no fire treatments. In the absence of greater spatial and temporal replication, the interpretation at this stage is speculative, but sets the scene for future data collection and analysis. Nevertheless, key aspects and questions from these initial interpretations and assessments should be explored further.

As expected, and as a result of their finer texture soils, the basalt EBPs have a $K_{\text {sat }}$ distribution of an order of magnitude lower than the granite EBPs. Meanwhile, there is generally greater $K_{\text {unsat }}$ at the surface on the granite EBPs annual burn plots versus the control plots, than compared to the similarity observed within the basalt annual burn and control plots. 


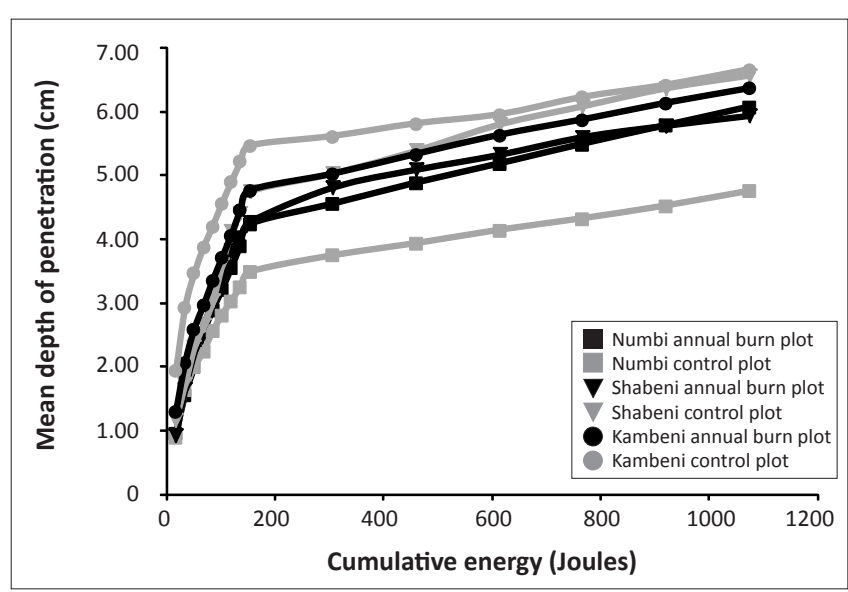

Data are averages of 10 readings at each site.

FIGURE 6: Drop cone penetrometer data from the granite experimental burn plots in the Kruger National Park.

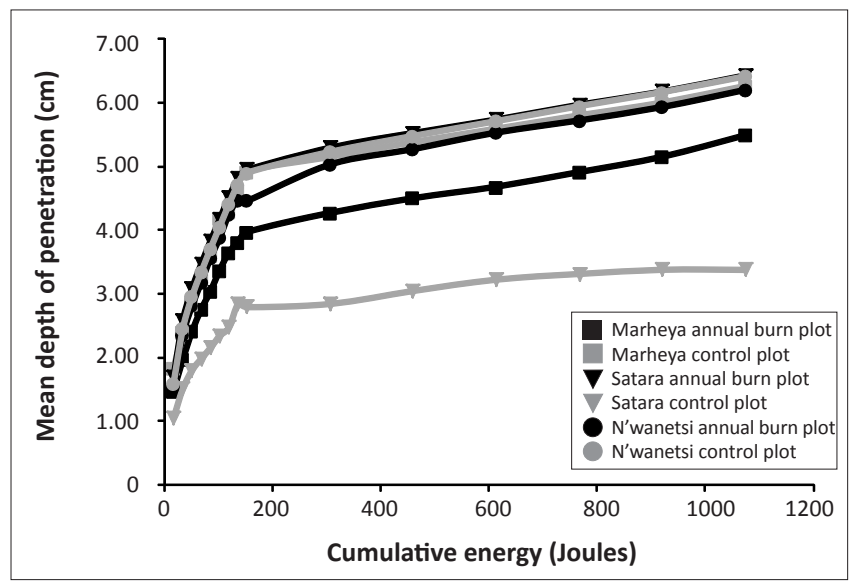

Data are averages of 10 readings at each site.

FIGURE 7: Drop cone penetrometer data from the basalt experimental burn plots in the Kruger National Park.

Furthermore, the $K_{s a t}$ at the surface is distinctly higher than at depth on the annual burn plots of the granite EBPs. These effects seen on the granite EBPs could be attributed to the loss of organic residues at the soil surface caused by longterm fire treatments, which would explain these higher $K_{\text {sat }}$ and $K_{\text {unsat }}$ values of the annual plots. As demonstrated by Fynn, Haynes and O'Connor (2003), organic carbon was significantly reduced within the first $2 \mathrm{~cm}$ of the soil profile under repeated grassland dry annual and biennial winter fire treatments at Ukalinga in KwaZulu-Natal. Similar results were described by Mills and Fey (2004) on the granite EBPs at Numbi, but also the Napi plots in the Skukuza EBP strings. Recently, soil carbon was also shown to be lower on dry annual burn plots than the controls in the Mopani EBPs on basalt (Holdo, Mack \& Arnold 2011). Whilst the N'wanetsi string, also on basalt and following 30 years of fire treatment, showed a quarter lower organic carbon content in the control than on the annual, biennial and triennial burn plots (Jones et al. 1990).

The observed switch in $K_{\text {sat }}$ trends between the surface and deeper layers, as noted on the granite EBPs, is also a point of interest. The differences noted at depths below the surface, such as $K_{s a t}$ and the soil strength, could simply be a result of inherent site differences such as soil morphological characteristics associated with different slope angles and position of measurements in the landscape; this is highly likely in the undulating landscape of Pretoriuskop. This points to the need for greater replication and spatial coverage in future studies of this type to isolate for such heterogeneous influences in the analysis. However, it is feasible that the lower $K_{\text {sat }}$ on the annual plots on the granite EBPs soil surface may result from changes in the soils sorptivity resulting from ash deposition, the effects of which can be markedly variable depending on the texture of the soil (see e.g. Moody, Kinner \& Úbeda 2009). This also points to the need in future to examine explicitly soil sorptivity characteristics resulting from fire.

However, the basalt EBPs show a smaller variation in $K_{\text {sat }}$ and $K_{\text {unsat }}$ on the annual treatments than the control plots, which may result from the development of a relatively homogenous soil layer structure on the more frequently burnt plots. This could be caused by a loss of organic matter and downward illuviation of finer material and ash deposits. The basis for this theory arises from two aspects. Firstly, the influence and importance of organic matter content on soil sheer strength is further demonstrated by Ekwue (1990), who showed that soil shear strength increased as a result of grass derived organic matter content. Therefore, the annually burnt basalt plots of the KNP have reduced soil strength as a result of a loss of organic carbon caused by frequent grassland vegetation fires at the site. This will make the soils on burnt areas within basalt both susceptible to erosion and have reduced soil moisture retention properties. The above results of deeper soil penetration per unit energy on the annual basalt plots described in this communication would support this hypothesis. Secondly, DeBano (2000) discusses the role of fires in facilitating the development of a water repellent layer in the soil subsurface. The frequent annual burning on the basalt EBPs could lead to the formation of a water repellent layer below the surface, rather than as a crust at the surface as suggested by Mills and Fey (2004). The small variation in $K_{\text {sat }}$ at $5 \mathrm{~cm}$ on the basalt annual burn plots compared to the control plots is supportive of this theory, but warrants more detailed assessment, replication and analysis.

Seemingly, the same effects could also have occurred on the coarser soils of the granite EBPs. Whilst these may not be apparent within the limited analysis described here, the intricacies of different fire severities associated with soils of different textures on changes in aggregate stability warrants further determination (for a review see Mataix-Solera et al. 2011). Moreover, both granite and basalt EBPs showed high compaction beyond $5 \mathrm{~cm}$ soil depth in the penetrometer analysis and a concomitant similarity in $K_{\text {sat }}$ between annual burn and control treatments beyond $5 \mathrm{~cm}$. This suggests that fire effects on soil hydrology may be most significant within the first $5 \mathrm{~cm}$ of soil and should also be investigated further by analysis using parameters such as soil bulk density and rooting density, especially to complement further penetrometer data. 
Results from this preliminary assessment of the impact of long-term fire treatments on in situ soil hydrology indicate that frequent hot fires lead to structural homogenisation of the soil surface particularly on basalt soils. Interpretation of this dataset requires cognisance of other recent findings on the effects of fire frequency and season on the KNP landscape. The reduction in woody vegetation cover as a result of frequent burning (Smit et al. 2010) and increase in small tree dominance under frequent burning (Higgins et al. 2007) are bound to have an effect on soil structure, as suggested by the scale dependent controls on biogeochemical processes resulting from tree canopy size (Holdo et al. 2011). Results will need to be discussed in this light. Whilst most interpretations and explanations have focused on the vegetation (both woody and grass) feedbacks on soil hydrological properties through a fire driven system, changes in herbivore utilisation and density (e.g. Burns et al. in review) and resultant trampling and nutrient deposition as a result of fire treatments also need to be considered.

\section{Conclusion}

This study indicated interesting geologically specific feedbacks between fire and soil hydrology. These need to be more thoroughly determined in order to quantify the impacts of soil crusting and water repellency resulting from fire on plant available water in the savannah landscape. The EBP experiment provides a valuable opportunity to explore the role of fire management policies on soil hydrological properties at point and plot scales, with the added benefit that the experiment allows for the inter-comparison between geological settings. The results presented here have suggested that the effects of fire management on soil hydrology become more apparent on the finer texture basalt soils than the coarser granites. However, future studies of this nature should be based on a more comprehensive, replicated and multifactorial analysis. These should focus on quantifying the variation of pyro-hydrological interaction both between geologies, but also the nuances that may be associated with fire frequency and intensity of burn within geologies, as well as an explicit assessment of the influence of slope and landscape position, amongst other aspects.

\section{Acknowledgements}

The authors acknowledge the contributions from the following people: Dr Pieter Le Roux (University of the Free State) for assisting with site selection based on soil diagnostics, Renson Thethe and Thomas Rikombe (both South African National Parks) for protection whilst in the field and Johannes Hachmann (Vrije Universiteit, the Netherlands) for providing additional assistance during the field campaign. The authors are also grateful for the useful comments provided by two anonymous referees.

\section{Competing interests}

The authors declare that they have no financial or personal relationship(s) which may have inappropriately influenced them in writing this paper.

\section{Authors' contributions}

E.S.R. (University of KwaZulu-Natal) was responsible for the methodological design, data collection and analyses used in this study. He was also responsible for analysing the results and compiling the manuscript. A.K. (University of KwaZuluNatal), B.M. (University of KwaZulu-Natal), S.N. (University of KwaZulu-Natal), J.P. (University of KwaZulu-Natal), A.P. (University of KwaZulu-Natal), J.P. (University of KwaZuluNatal) and Z.S. (University of KwaZulu-Natal) were responsible for data collection and analysis. S.A.L. (University of KwaZulu-Natal) contributed to the methodological design and was also responsible for data collection. N.G. (South African National Parks) provided the team with background information on the EBPs, logistical support during the campaign and made valuable contributing comments to the manuscript.

\section{References}

Andersen, A.N., Cook, G.D. \& Williams, R.J., 2003, Fire in tropical savannas: The Kapalga experiment, Springer Verlag, New York.

Biggs, R., Biggs, H.C., Dunne, T.T., Govender, N. \& Potgieter, A.L.F., 2003, 'Experimental burn plot trial in the Kruger National Park: History, experimental design and suggestions for data analysis', Koedoe 46(1), 1-15.

Bijker, H.J., Sumner, P.D., Meiklejohn, K.I. \& Bredenkamp, G.J., 2001, 'Documenting the effects of veld burning on soil and vegetation characteristics in Giant's Castle Game Reserve, KwaZulu-Natal Drakensberg', South African Geographical Journal Game Reserve, KwaZulu-Natal Drakensberg', South African Geogrd
83, 28-33. http://dx.doi.org/10.1080/03736245.2001.9713716

Bond, W.J. \& Keeley, J.E., 2005, 'Fire as a global herbivore: The ecology and evolution of flammable ecosystems', Trends in Ecology and Evolution 20(7), 387-394. http:// dx.doi.org/10.1016/j.tree.2005.04.025

Brown, J.A.H., 1972, 'Hydrologic effects of a bushfire in a catchment in southeastern New South Wales', Journal of Hydrology 15, 77-96. http://dx.doi. org/10.1016/0022-1694(72)90077-7

Burns, C.E., Zinn, A.D., Govender, N., Buis, G.M. \& Smith, M.D., in review, 'The distribution of large herbivores in a fire-managed savanna grassland: Assessing the role of bottom-up processes', Oikos.

DeBano, L.F., 2000, 'The role of fire and soil heating on water repellency in wildland environments: A review', Journal of Hydrology 231, 195-206. http://dx.doi. org/10.1016/S0022-1694(00)00194-3

Eijkelkamp Agrisearch Equipment, 2008, Operating instructions: Geulph permeameter Giesberg, the Netherlands, viewed 18 December 2011, from http://pkd. eijkelkamp.com/Portals/2/Eijkelkamp/Files/Manuals/M1-0907e\%20Guelph\%20 permea.pdf

Eijkelkamp Agrisearch Equipment, 2009, Operating instructions: Pocket penetrometer Giesberg, the Netherlands, viewed 18 December 2011, from http://pkd. eijkelkamp.com/Portals/2/Eijkelkamp/Files/Manuals/M1-0603e\%20Pocket\%20 penetromet.pdf

Eijkelkamp Agrisearch Equipment, 2011, Operating instructions: Pocket vane tester, Giesberg, the Netherlands, viewed 18 December 2011, from http://pkd. eijkelkamp.com/Portals/2/Eijkelkamp/Files/Manuals/M1-1410e\%20Pocket\%20 vane\%20test.pdf

Ekwue, E.I., 1990, 'Organic-matter effects on soil strength properties', Soil and Tillage Research 16(3), 289-297. http://dx.doi.org/10.1016/0167-1987(90)90102-J

Fynn, R.W.S., Haynes, R.J. \& O’Connor, T.G., 2003, 'Burning causes long-term changes in soil organic matter content of a South African grassland', Soil Biology and Biochemistry 35(5), 677-687. http://dx.doi.org/10.1016/S0038-0717(03)00054-3

Gertenbach, W.P.D., 1983, 'Landscapes of the Kruger National Park', Koedoe 26, 9-121.

Herrick, J.E. \& Jones, T.L., 2002, 'A dynamic cone penetrometer for measuring soil penetration resistance', Soil Science Society of America Journal 66, 1320-1324. http://dx.doi.org/10.2136/sssaj2002.1320

Higgins, S.I., Bond, W.J. \& Trollope, W.S.W., 2000, 'Fire, resprouting and variability: A recipe for grass-tree coexistence in savanna', Journal of Ecology 88, 213-229. $\mathrm{http}: / / \mathrm{dx}$.doi.org/10.1046/j.1365-2745.2000.00435.x

Higgins, S.I., Bond, W.J., February, E.C., Bronn, A., Euston-Brown, D.I.W., Enslin, B. et al., 2007, 'Effects of four decades of fire manipulation on woody vegetation structure in savanna', Ecology 88(5), 1119-1125. http://dx.doi.org/10.1890/061664, PMid:17536398

Holdo, R.M., Mack, M.C. \& Arnold, S.G., 2011, 'Tree canopies explain fire effects on soil nitrogen, phosphurus and carbon in a savanna ecosystem', Journal of Vegetation Science 23(2), 352-360. http://dx.doi.org/10.1111/j.1654-1103.2011.01357.x

Jones, C.L., Smithers, N.L., Scholes, M.C. \& Scholes, R.J., 1990, 'The effect of fire frequency on the organic components of a basaltic soil in the Kruger National Park', South African Journal of Plant Soil 7(4), 236-238. 
Knapp, A.K., Briggs, J.M., Hartnett, D.C. \& Collins, S., 1998, Grassland dynamics: Long term ecological research in tallgrass prairie, Oxford University Press, New York.

Lindley, A.J., Bosch, J.M. \& Van Wyk, D.B., 1988, 'Changes in water yield after fire in fynbos catchments', Water SA 14(1), 7-12.

Lorentz, S., Thornton-Dibb, S., Pretorius, J.J. \& Goba, P., 2003, Hydrological systems modelling research programme: Hydrological processes. Phase II quantification of hillslope, riparian and wetland processes, Report to the Water Research Commission on the Project A field study of two and three dimensional processes, WRC Report K5/1061, Water Research Commission, Pretoria.

Mataix-Solera, J., Cerda, A., Arcenegui, V., Jordán, A. \& Zavala, L.M., 2011, 'EarthScience reviews fire effects on soil aggregation: A review', Earth Science Reviews 109(1-2), 44-60. http://dx.doi.org/10.1016/j.earscirev.2011.08.002

Mills, A.J. \& Fey, M.V., 2004, 'Frequent fires intensify soil crusting: Physicochemical feedback in the pedoderm of long-term burn experiments in South Africa', Geoderma 121, 45-64. http://dx.doi.org/10.1016/j.geoderma.2003.10.004

Moody, J.A., Kinner, D.A. \& Úbeda, X., 2009, 'Linking hydraulic properties of fireaffected soils to infiltration and water repellency', Journal of Hydrology 379(3-4) 291-303. http://dx.doi.org/10.1016/j.jhydrol.2009.10.015

Pierson, F.B., Williams, C.J., Hardegree, S.P., Weltz, M.A., Stone, J.J. \& Clark, P.E., 2011 'Fire, plant invasions, and erosion events on western rangelands', Ecology 64(5), 439-449.

Scholes, R.J. \& Hall, D.O., 1996, 'The carbon budget of tropical savannas, woodlands and grasslands', in A.I. Breymeyer, D.O. Hall, J.M. Melillo \& G.I. Agren (eds.), Global change: Effects on coniferous forests and grasslands, pp. 69-100, Wiley, Chichester.

Scholes, R.J. \& Walker, B.H., 1993, An African Savanna - Synthesis of the Nylsvley study, Cambridge University Press, Cambridge. http://dx.doi.org/10.1017/ CBO9780511565472
Scott, D.H., 1997, 'The contrasting effects of wildfire and clearfelling on the hydrology of a small catchment' Hydrological Processes 11, 543-555, http://dx.doi. org/10.1002/(SICI)1099-1085(199705)11:6<543::AID-HYP474>3.0.CO;2-」

Smit, I.P.J., Asner, G.P., Govender, N., Kennedy-Bowdoin, T., Knapp, D.E. \& Jacobson, J. 2010, 'Effects of fire on woody vegetation structure in African Savanna', Ecological Applications 20(7), 1865-1875. http://dx.doi.org/10.1890/09-0929.1

Soil Classification Working Group, 1991, Soil classification: A taxonomic system for South Africa. Memoirs on the Agricultural Natural Resources of South Africa No. 15. Soil and Irrigation Research Institute, Department of Agricultural Development, Pretoria.

STATEXT version 1.4, 2011, computer software, viewed 06 December 2011, from http://www.statext.com

Townsend, S. \& Douglas, M., 2000, 'The effect of three fire regimes on stream water quality, water yield and export coefficients in a tropical savanna (northern Australia)', Journal of Hydrology 229, 118-137. http://dx.doi.org/10.1016/S0022 1694(00)00165-7

Van der Schijff, H.P., 1958, Inleidende verslag oor veldbrandnavorsing in die Nasionale Krugerwildtuin [Preliminary report on wildfire research in the Kruger National Park]. Koedoe 1, 60-93.

Venter, F.J. \& Govender, N., 2012, 'A geomorphic and soil description of the long-term fire experiment in the Kruger National Park, South Africa', Koedoe 54(1), Art. \#1037, 10 pages. http://dx.doi.org/10.4102/koedoe.v54i1.1037

Walter, H., 1971, Ecology of tropical and subtropical vegetation, 1st edn., Oliver \& Boyd, Edinburgh.

Webber, C.N., 1979, 'The effects of fire on soil-plant ecological relationships in the southern part of the Kruger National Park: A study in soil geography', MSc thesis, Dept. of Geography, University of Pretoria. 